\title{
Mellem natur og kultur
}

\author{
af Ove Korsgaard
}

En af de største gåder i den danske idrætshistorie er spørgsmålet: Hvorfor begyndte de grundtvigianske bønder fra 1884 frivilligt at dyrke en gymnastik, som man $i$ andre lande - og også herhjemme - måtte gøre obligatorisk i skolen og/eller hæren for at få denne disciplinering af kroppen gennemført?

Er det fordi selvdisciplineringen satte sig stærkere igennem hos de danske bønder, eller fordi de gjorde erfaringer med den svenske gymnastik, som man ikke gjorde andre steder?

Disse spørgsmål er baggrunden for de følgende overvejelser.

Grundtvigianerne begyndte ikke at dyrke svensk gymnastik, fordi de blev opfordret dertil af den tids autoriserede gymnastiklærere, der overvejende var officerer. Tværtimod.

Med kaptajn Edvard Nielsen som initiativtager underskrev 46 officerer i 1887 en fælleserklæring, hvori de skarpt tog afstand fra højskolernes arbejde på at udbrede den svenske gymnastik til skytteforeninger:

»Undertegnede Officerer fra Garnisonerne Fredericia, Nyborg, Odense, Aarhus, Viborg, Aalborg, Randers, Horsens, Kjøbenhavn udtale herved, at vi anse det meget forkasteligt, at der er Amts Skytteforeninger her i Landet, der have indført svensk Gymnastik i Skytte Kredsene og til den Ende uddannet Lærere i nævnte Gymnastik ved visse Højskoler, medens at den danske militære Gymnastik efter at have faaet en saa stor Udbredelse i Danmark som intetsteds nu fortrænges i en Del af de under Overbestyrelsen sorterende Amtsskytteforeninger. Vi vilde anse det for heldigt, om disse Foreninger atter vendte tilbage til den Gymnastik, som for Skytterne, de vordende Soldater, absolut vilde være den gavnligste $\ll$.

I et ledsagebrev anbefalede Edvard Nielsen skytteforeningerne at udmelde sig amtsvis af De danske Skytteforeninger og danne en ny sammenslutning med et rent militært formål. Han ville ikke være med i en sammenslutning:

»med de af Højskolerne paavirkede Folk, thi visse Skolers Aand er saa radikal og saa samfundsopløsende, at det er en Lettelse at være dem kvit; det forekommer mig umuligt at samarbejde med dem paa Grund af deres hele Livssyn «.

På trods af officerernes advarsler gik man i mange skytteforeninger over til den svenske gymnastik. Allerede i 1887 var der således i Ribe amt et flertal, elleve kredse mod 
ti, der dyrkede svensk gymnastik. Og på landsplan var det gymnastiske systemskifte gennemført omkring århundredeskiftet.

I 1901 blev den sjette almindelige Skytte- og Gymnastikfest afholdt i København. Det var ingen tilfaldighed, at festen var henlagt til hovedstaden. Nu skulle den grundtvigianske bondekultur vise byen, hvad landet kunne præstere på det idrætslige område. Næsten alle hold viste svensk gymnastik. De få hold, der viste dansk, var overvejende købstadsfolk, der kritiserede den svenske gymnastik, bl.a. for at hæmme den dygtige og lægge for lidt vægt på enkeltmandspræstationer.

\section{Struktur og kultur}

At gymnastikken kunne blive genstand for så stærke følelser som tilfældet var i slutningen af det forrige århundrede kan undre. På en lang række områder var der nemlig ikke den store forskel mellem den tysk/danske gymnastik og den svenske. Mange af de samme elementer gik igen i de to systemer: gang, løb, armbøjning, armhævning, lændebøjning o.s.v.

Den svenske gymnastik blev kaldt »artificiel «, da den i endnu højere grad end den danske byggede på »kunstige « bevægelser. Hovedindholdet var $\emptyset$ velser i ribber, bomme og tove og de såkaldte fritstående $\emptyset$ velser. Den danske gymnastik havde som en del af programmet de populære smidigheds $\varnothing$ velser, som var spring af forskellig art. Hvorvidt de skulle indoptages i en svensk domineret gymnastik blev et væsentligt stridsspørgsmål. Et af de afgørende kritikpunkter mod den svenske gymnastik var nemlig, at den var for ensformig, kedelig og stiv. Edvard Nielsen mente, at

»Den danske Gymnastik var efter sin Natur mere folkelig, idet den havde et legende Moment i sig; den svenske var ganske vist yndefuldere, isprængt med plastiske Fremstillinger; men den danske Gymnastik, beregnet paa det storé brede Folkelag, var baseret paa Kraften, Farten, Dristigheden «.

Men disse forskelle og stridigheder ændrer ikke ved, at der på de afgørende områder var store ligheder mellem de to gymnastiksystemer.

Var de strukturelle forskelle mellem den svenske gymnastik og den danske ikke markante, var de kulturelle det til gengæld. Selv små forskelle i indhold var tilstrækkeligt store til, at den svenske gymnastik kunne lades med en symbolbetydning, der i kropsbilleder udtrykte, at dette her var de grundtvigianske bønders gymnastik. Den var anderledes end den gamle militærgymnastik, knyttet til officersstanden, og adskilte sig også fra den nye engelske sport, der begyndte at vinde frem i byerne.

Sin betydningsladning fik gymnastikken i de politiske kampår, der fandt deres foreløbige afslutning med parlamentarismens indførelse i 1901. Gymnastikken udtrykte for grundtvigianerne fællesskab og samhørighed. Og den bidrog til at give den grundtvigianske bondekultur en selvstændig identitet på det legemskulturelle område.

\section{Anatomi, demokrati og lovsang}

Tilhængere af den svenske gymnastik argumenterede på tre niveauer for denne gymnastiks fortrin: et naturvidenskabeligt, et social-kulturelt og et åndeligt niveau.

For det første kunne den svenske gymnastik gøre kroppen mere harmonisk. Den byggede på et indgående kendskab til anatomi, fysiologi og patologi, og var således na- 
turvidenskabeligt funderet. Gennem et hensigtsmæssigt øvelsesvalg kunne man fjerne eller afhjælpe uhensigtsmæssige spændinger, uharmonier og ubalancer, som det hårde slid ved landbruget (nødvendigvis) påførte kroppen. Den svenske gymnastik var således hygiejnisk og terapeutisk i sit udgangspunkt og stilede mod kropslig harmoni. Poul la Cours synspunkt var, at »vort Legeme er et stykke Natur«, hvor de samme love gælder, som i den øvrige natur. I en lærebog til brug i gymnastik skrev han:

»Det er derfor en Selvfølge, at jo mere vi indretter vort Liv efter de krav, som Naturen stiller, og efter de Maal, hvortil vort Legeme er bestemt, des fulkomnere vil dette staa til vor Raadighed «.

For det andet skulle den svenske gymnastik på det socialt-kulturelle niveau bidrage til den rette balance mellem kappestrid og fællesskab. For at den kunne udvikles, måtte man ifølge la Cour klargøre sig forskellen mellem to former for kappestrid. I konkurrencen stræber man efter individuelt at blive så dygtig som muligt for derved at komme til at glimre i sammenligning med andre, mindre dygtige. I kappestriden stræber man ivrigt mod et fælles mål. Der skulle stræbes, men stræbes i flok. For la Cour førte konkurrence til en individualisme på fællesskabets bekostning. Han anså den svenske gymnastik som velegnet til fremme af fællesskabet. Gennem den rigtige øvelsessammensætning kunne alle være med på holdet. Udgangspunktet var det enkelte menneske i fællesskab med andre. Fritstånde øvelser i hold blev derfor foretrukket frem for smidighedsøvelser udført enkeltvis. Den svenske gymnastik blev fremhævet som almen tilgængelig, demokratisk og folkelig.

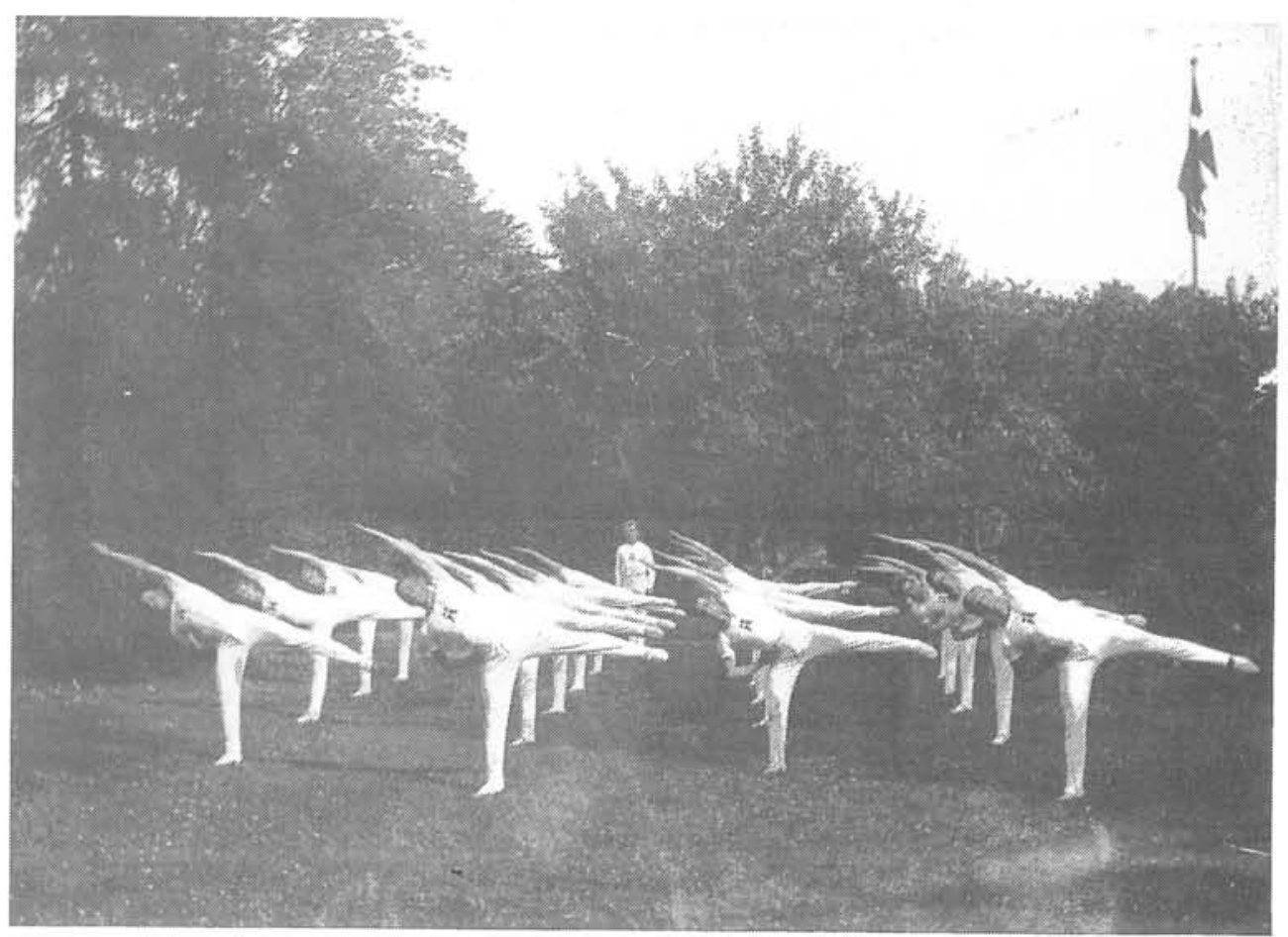


For det tredje kunne den svenske gymnastik hjælpe kroppen til »at synge en Lovsang til Skaberens Ære«, som la Cour udtrykte det på Vallekilde. Et vigtigt element i den svenske gymnastik var de formgivende $\emptyset$ velser. En bevægelse skulle ikke blot fremme sundheden, men også skønheden. Ved at skabe smukke øvelser var det ikke kun legemets, men også sjælens behov, som blev tilgodeset. De formgivende $\emptyset v e l s e r$ blev betragtet som et middel til at løfte sjælen og gøre sindet rankt og frit.

At ikke kun ordet var gudsbilledligt, men også kroppen trak Ernst Trier frem i sin tale 1884, hvor han henviste til Grundtvig, der i en salme lægger Gud følgende ord i munden:

Mon mit Aasyn ej afpræger

Boldt sig i det bløde Ler.

Med baggrund i en sådan tolkning åbnes der for en forståelse af gymnastik som en art kunstnerisk skabelse, der forbinder ydre og indre menneskelig natur og lader begge komme til udfoldelse.

Hvordan gymnastik kan forbinde den ydre og indre natur havde grundvigianerne imidlertid svært ved at udtrykke i ord; ofte blev de bragt i forlegenhed og holdt sig til naturvidenskabelige argumenter, men ind imellem kommer der poetiske vendinger og slagord som »at sætte et adelsmærke på kroppen«, »at løfte hovedet, så lyset kan falde på det«, »at få det gudsbilledelige frem i mennesket«, »at løfte hovedet på en nordisk måde «, »at svinge armen som en svalevinges flugt gennem luften«. Ved hjælp af den slags poetiske vendinger søgte grundtvigianerne at udtrykke den åndelige dimension $\mathrm{i}$ gymnastikken.

Man argumenterede således både ud fra en snæver videnskabelig tankegang: at der findes anatomisk-fysiologisk korrekte kropsholdninger og -bevægelser, og ud fra en bredere kulturel tankegang: at de rette kropsholdninger og -bevægelser forløser åndelige værdier og holdninger. Kroppen er på èn gang af biologisk natur og en åndelig skabning.

Imidlertid forblev det et uafklaret spørgsmål for grundtvigianerne, hvorledes forholdet mellem det biologiske og åndelige i legemskulturen nærmere skal udredes. De svingede mellem at betone snart den ene og snart den anden dimension.

\section{Magt og videnskab}

På kompleks vis væver det (magt)politiske spil mellem godsejer-, officers- og embedsstanden på den ene side og bondestanden og højskolefolk på den anden side sig ind i denne problemstilling.

Tilhængere af den svenske gymnastik brugte ofte en argumentation, der byggede på, at denne gymnastik i modsætning til den danske var videnskabeligt funderet. Og man angreb lærerne i den danske gymnastik for at være fuskere, der ikke kendte til anatomi og fysiologi.

Med disse videnskabelige synspunkter satte højskolefolk ind med en sønderlemmende kritik af Hærens Gymnastikskole, der gennem det meste af århundredet gav den højeste uddannelse inden for gymnastik. Ved at betone det videnskabelige aspekt 
så stærkt, truede man hærens monopol på at være normdannende for næsten al gymnastik i Danmark.

I løbet af få år lykkedes det faktisk for højskolen at skabe et alternativ til uddannelsen i dansk gymnastik efter militære normer. Gennem et samspil mellem nogle få, der tog en to-årig uddannelse i svensk gymnastik på Centralinstituttet i Stockholm, og de mange, der blev uddannet som delingsførere på højskolerne, formåede højskolen at bryde hærens monopol på gymnastikområdet.

Men denne pukken på den svenske gymnastiks videnskabelighed viste sig at være et tveægget sværd. Den blev et brækjern i nedbrydningen af hærens normdannende indflydelse på gymnastikken, men samtidig en trussel mod en væasentlig drivkraft i dette opgør, nemlig den folkelige tilgang og den kulturelle manifestation. Der kom en indre spænding i den grundtvigianske gymnastikkultur mellem det videnskabelige, terapeutiske, hygiejniske og pædagogiske på den ene side og kampen mod formyndere og eksperter og for selvforvaltning på den anden.

\section{Videnskab og opdragelse}

Blandt tilhængerne af den svenske gymnastik gjorde der sig imidlertid to synspunkter gældende, som vanskeligt lod sig forene. Det ene synspunkt repræsenteredes af universitetsfolk som K. Kroman og J. Lindhard, det andet synspunkt af højskolefolk som Poul la Cour og Ernst Trier. K.A. Knudsen fors $\emptyset$ gte uden held at forene disse synspunkter.

Kristian Kroman var professor i filosofi og tillige undervisningsministeriets skolekonsulent og formand for Gymnastikkommissionen, der fra 1889 til 1899 udarbejdede Gymnastikhaandbogen (1899), der betød en fuldstændig omlægning af skolegymnastikkens indhold. Den svenske gymnastiks principper blev nu lagt til grund for den egentlige gymnastik, der skulle suppleres med en blanding af gamle lege og nye engelske sportsdiscipliner, som blev kaldt anvendt gymnastik. Med håndbogen gik staten nu i spidsen for udbredelse af legems øvelser, der var i overensstemmelse med naturvidenskabelige kriterier.

Kroman var meget optaget af naturvidenskab og blev dr. phil. på spørgsmålet om »den eksakte Videnskabs indlæg i Problemet om Sjælens Eksistens«, hvor han overførte naturvidenskabens metode på filosofi. Han afviste metafysiske spørgsmål og fremhævede stærkt, hvor nødvendigt det er for den filosofi, der vil kaldes videnskab, at tilegne sig den naturvidenskabelige forsknings eksakthed og metode. Senere overførte han denne tankegang på pædagogik. Hans opfattelse var, at naturvidenskaben har givet mennesket et opdragelsesmiddel i hænde, som i mange henseender pædagogisk overgår alt. På grund af de videnskabelige principper betragtede Kroman det svenske gymnastiksystem som et mesterværk, »Det er absolut det mest fuldkomne, der er fremkommen paa Pædagogikkens Omraade«. Et forbillede for andre områder.

\section{Noget grundvigiansk-svensk jux}

Samme år, som håndbogen i gymnastik udkom, var Kroman medstifter af »Gymnastisk Selskab «, hvis formål var at virke til forståelse af rationel gymnastik, at virke til dens videre udvikling, dens udbredelse og dens rette stilling og anvendelse.

Selskabet var i begyndelsen en forening for tilhængere af rationel gymnastik i København, men fik snart medlemmer over hele landet, deriblandt mange grundtvigianere. 
Men den stigende grundtvigianske indflydelse huede ikke Kroman. I et brev til K.A. Knudsen skrev han i 1906:

»Jeg har allerede faaet Opfordring til at være med til at stifte et nyt Gymnastik Selskab, der først og fremmest kræver Hensyn til Skolens Tarv, medens Gymnastisk Selskab nærmest er blevet en Slags Fagforening for grundtvigiansk fri Gymnastik. Jeg tror, vi skal være meget varsomme med saa udelukkende at betone det svenske og det grundtvigianske. Faar vi om kortere eller længere Tid et nyt Ministerium, vil det jo sikkert blive ganske antigrundtvigiansk og temmelig antisvensk, og kommer saa samtidig vore Modstandere hjem fra Athen med Laurbær, saa kan den nye Gymnastik endnu godt blive kasseret som noget grundtvigiansk-svensk Jux.«

Såvel skolefolk som højskolefolk var tilhængere af den svenske gymnastik, men ud fra forskellige begrundelser. Kroman skelnede mellem rationel skolegymnastik og grundtvigiansk fri gymnastik, der rummede en række politiske, kulturelle og åndelige overtoner, han tog skarpt afstand fra. Som skolekonsulent var han tilhænger af den svenske gymnastiks principper, fordi de var rationelle, hygiejniske, pædagogiske og videnskabelige.

Også højskolefolk argumenterede for det samme, men ofte med et videnskabsbegreb, farvet af romantikkens naturfilosofi, der lagde vægt på at se »enheden i mangfoldigheden«, og »ånden i naturen .

Mens Kroman således alene søgte et videnskabeligt udgangspunkt for gymnastikken, søgte grundtvigianerne at forene det med et kulturelt og åndeligt udgangspunkt. Grundtvigianerne ville »mere « end hygiejne, pædagogik og videnskab med gymnastikken: den skulle forene og udvikle både krop og sind.

\section{K.A. Knudsen og Johs. Lindhard}

K.A. Knudsen søgte med udgangspunkt i højskolen at bygge bro til skolefolk. Han blev af den svenske fløj i 1898 gjort til lærer på det nyoprettede årskursus i gymnastik på Danmarks Lærerhøjskole, som det hedder i dag. Det skete efter et bittert opgør med den danske fl $\varnothing \mathrm{j}$, der ville have Paul Petersen, en hovedfigur inden for den danske gymnastik. Ydermere blev K.A. Knudsen i 1904 den første civile siden Nachtegall, der fik stillingen som gymnastikdirektør, landets højeste embede inden for gymnastik.

K.A. Knudsen var derfor selvskreven som forstander for Statens Gymnastikinstitut, der blev oprettet i 1911. Dér gjorde han den svenske gymnastik til det centrale og søgte at holde sporten ude.

I 1909 blev læge Johs. Lindhard ansat som lektor og senere professor i gymnastikteori ved Københavns Universitet og videreførte her Kromans synspunkter. K.A. Knudsen og Johs. Lindhard skulle dermed arbejde sammen om den højere uddannelse $i$ gymnastik, idet den praktiske del af uddannelsen foregik på Statens Gymnastikinstitut og den teoretiske del på Københavns Universitet.

Men samarbejdet gik hurtigt $\mathrm{i}$ hårdknude. Lindhard angreb med bidende sarkasme Knudsens opfattelse af, at der var en forbindelse mellem en god og sund holdning på den ene side og en smuk på den anden. Han mente, at det var overtro og byggede på 
dogmer. Til at afklare den slags havde man videnskaben, sagde Lindhard, og gik i gang med at undersøge den gode holdning i de dertil indrettede laboratorier; og der gik ikke lang tid før han med triumf konstaterede, at der ikke kunne påvises en forbindelse mellem en god og sund holdning og så en smuk. Det eneste, man kunne sige, var, at gymnastikken kun i få tilfælde havde gjort direkte skade!

Det synspunkt vakte stor harme i den svenske gymnastiks lejr. Og der kom til at herske næsten borgerkrigslignende tilstande inden for den højere uddannelse. Striden fik nemlig et yderst dramatisk forløb. Den blev for alvor kendt af offentligheden, da Lindhard støttede en udtalelse om, at Knudsen var uduelig som forstander og uhæderlig som videnskabsmand.

Det første sigtede bl.a. til, at Knudsen af al magt ville fastholde den svenske gymnastiks position over for sporten, det andet at han skulle have forfalsket resultaterne af nogle videnskabelige undersøgelser, så de kom til at passe til hans egne teorier om den gode holdning.

Undervisningsministeriet fors $\emptyset$ gte at få Knudsen til at trække sig tilbage som forstander. Men det nægtede han og anlagde i stedet injuriesag mod Lindhard-fløjen. Den tabte han næsten fuldstændig ved byretten, men appellerede og blev delvist renset ved landsretten. Sagen bragte imidlertid så mange konflikter for dagen, at han blev nødt til at trække sig tilbage i 1927, selv om han blev kraftigt støttet af grundtvigianerne. Striden sluttede således med en fuldstændig sejr for Lindhard og hans positivistiske videnskabssyn og et ydmygende nederlag for Knudsen og hans romantisk inspirerede forståelse. Lindhard blev selv tre år senere forstander på Statens Gymnastikinstitut.

Bag Lindhards angreb på Knudsen lå et mere fundamentalt opgør med resterne af den gymnastikteori, som skaberen af den svenske gymnastik, P. H. Ling, havde udviklet, stærkt inspireret af naturfilosofien. For Lindhard havde en sådan teori intet méd videnskab at gøre.

Han støttede sig til en positivistisk opfattelse, at det gælder om at holde sig til det, der kan sættes tal på og lade holdninger og værdier ude af betragtning. Der skelnes skarpt mellem kendsgerninger og personlige vurderinger. Kendsgerninger er noget objektivt, vurderinger noget subjektivt. Og derfor har det ingen mening for positivisten at tale om »den gode holdning« som en blanding af noget objektivt og subjektivt, af natur og kultur.

Da den positivistiske naturvidenskab med Lindhard i spidsen begyndte at analysere »den gode holdning « under mikroskop, blev Knudsen - og mange andre - presset ud i tovene; og han gik i den fælde, at han prøvede at bevise forbindelsen mellem den gode, sunde og den smukke holdning med modstanderens midler, d.v.s. ved hjælp af den positivistiske videnskabs metoder. Og det blev hans tragedie.

Blandt naturvidenskabsmænd har der siden opgøret mellem Lindhard og Knudsen været enighed om, at førstnævnte havde ret. Lægen og videnskabsmanden satte den teologisk uddannede K.A. Knudsen til vægs. Lindhard var medstifter af det senere så berømte August Krogh Institut, der blev banebrydende inden for den nyere fysiologiske forskning. Der har hans elever fortsat den »afmytologisering «, som Kroman og Lindhard påbegyndte. Og disse fysiologer har siden været autoriteter i idrætsteori. De forkastede »den gode holdning" - og stillede ikke andet and tal i stedet. 


\section{Anatomi og astetik}

Selv forkastede Lindhard ikke æstetiske og etiske overvejelser, tværtimod; og han skrev præcise og afslørende ting om sportens èndimensionalitet. Men med sit positivistiske videnskabssyn var han selv med til at bane vejen for en udvikling af sportens princip og til at undergrave grundtvigianernes fors $\varnothing \mathrm{g}$ på i gymnastikken at forbinde krop og sind og lade begge komme til udfoldelse. Han kappede forbindelsen mellem på den ene side anatomi, fysiologi og biologi og på den anden etik, æstetik og poesi.

Han forkastede derfor fuldstændig Lings gymnastikteori og vurderede hans: »Gymnastikkens Allmänna Grunder « til at være »en syg Mands Værk «, hvis første kapitel for ham at se isar var fyldt med vilde »Spekulationer

Blandt Lings vilde spekulationer var en naturfilosofisk forestilling om, at kroppen rummer energier, elektromagnetiske kræfter, som kan overskride dens grænser og udstråle fra den. For ham var den erotiske erfaring et vidnesbyrd herom. Og det tolkede han som tegn på, at der i ethvert samspil mellem mennesker indgår sådanne kræfter, hvorfor denne »magnetisme « for ham var en kulturel faktor. Og idet han betragtede disse kræfter som en kosmisk energi, der forbandt ydre og indre natur, så anså han gymnastikken for en metode til at træde i kontakt med og lære at bruge disse energier. Det var derfor hans opfattelse, at enhver teori om gymnastik nødvendigvis må forbindes med en teori om kultur og kosmos.

Det feltenergibegreb, som antydes i Lings gymnastikteori, er siden blevet enten grundigt overset eller systematisk latterliggjort. Imidlertid er det et spørgsmål, om man kan »løse gåden « $\mathrm{i}$ den danske idrætshistorie uden brug af et sådant begreb eller et lignende, der henviser til det psykiske og sociale »overskud «, som gymnastiske øvelser og samværet i salen faktisk har vist sig at kunne udløse.

Strukturelt var der som nævnt ikke den store forskel mellem den tyske og svenske gymnastik, men kulturelt var der himmelvid forskel mellem gymnastikkens placering og betydning i Tyskland, Sverige og Danmark.

I den grundtvigianske kultur fik den svenske gymnastik tilført den dimension, der gjorde den til mere end eksercits. Den kom til at indgå i et symbolsk handlingsforløb og blev ladet med betydning og en oplevelsesfylde, der gjorde den kulturskabende.

For grundtvigianerne rummede denne gymnastik oplevelser, der vanskeligt lader sig erkende af en videnskab, hvis metoder alene er knyttet til positivismen. En videnskab, som ikke inddrager stemningen og atmosfæeren, får ikke fat i de følelsesmæssige oplevelser, der sikkert er af ligeså afgørende betydning som f.eks. økonomiske forhold i den historiske proces.

(Et omarbejdet uddrag af bogen Krop og Kultur - andelsbøndernes gymnastik mellem almuens leg og borgerskabets sport, 1986).

Ove Korsgaard, forstander på Gerlev Idratshøjskole. 